\title{
Money and Family Matter: Political Recruitment in the Golongan Karya Party of Banten Province
}

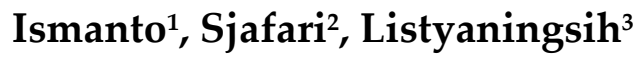 \\ 1Department of Public Administration, University of Sultan Ageng Tirtayasa (emailgandung@untirta.ac.id), \\ ²Email: agussjafari@untirta.ac.id, ${ }^{3} E m a i l:$ listyaningsih@untirta.ac.id
}

\begin{abstract}
Meritocracy is still a fundamental problem in political recruitment in Indonesia, especially in political parties. Although reform has penetrated all state institutions and the entire life of the nation and state, political parties became one of the institutions that remained unmoved by the old tradition even with several adaptations to follow the demands of democratization. This research was conducted with a qualitative approach to study the process of political recruitment in the Banten Province Golongan Karya Party, ahead of the 2019 General Election. It was chosen because of its existence as the most experienced major party. The results of the study prove that the poor face of political recruitment of legislative candidates is more determined by financial strength and nepotism. Formal selection is done, but the process is not accountable enough as well as the results. As a result, it will be closely related to the election of members of the legislature who have not only doubted their capabilities but also their integrity as reflected in the low quantity and quality of policies produced and the proliferation of corruption cases involving many legislative members at the central and regional levels.
\end{abstract}

\section{Keywords:}

legislators; dynasty; financial; meritocracy

\section{Introduction}

Political recruitment was pointed out as one of the root problems related to the low performance of the House of Representatives (DPR) for the 2014-2019 period (Formappi, 2018), which was only able to resolve approximately $10 \%$ of the total target of the national legislation program (Prolegnas) during the 2014- 2019 (ICW, 2019), and the low attendance of DPR members (wikidpr.org). The above note certainly does not include a number of cases of corruption by DPR members which has further worsened the institutional image of the DPR (liputan6.com) in the end, as well as a number of political decisions that tended to conflict with public expectations as reflected in the ratification of the Draft Law (RUU) which regulates Corruption Eradication Commission (KPK), as well as plans to ratify a 
number of RKUHPs, and other bills that are considered controversial both in the process and in substance. His discussion that is "running after" amid legitimacy that has "exhausted" gives a strong impression of the motive of "chasing deposits" that stimulates massive public reaction today.

The above description is also relevant to conditions at the local level. Although most members of the Banten Province DPRD have a minimum education level of $81.18 \%$ (dprdbantenprov.go.id); however, low productivity and discipline (news.detik.com) indicate the low capability of DPRD members in carrying out their duties and functions. Likewise with a number of cases that tarnished the face of the DPRD institutions, such as the bribery scandal of the establishment of Bank Banten involving 40 members of the Banten Provincial DPRD (beritasatu.com), including elements of the DPRD leadership (https://nasional.tempo.co), irrational budget of recess (bantennews.co.id), and unaccountable recess funds (rmolbanten.com), as well as the very low compliance of Banten Province DPRD members, which is only about $1.19 \%$, in reporting the assets of state administrators (LHKPN) (merdeka.com ) which as a whole are a public issue related to the performance of the Banten Province DPRD during the 2014-2019 period. The whole public issue is unable to change the negative image of the DPRD institution as passed down by the DPRD in the previous period, which not only acts as a power stamp but also becomes an effective instrument of power in carrying out political corruption in congregation and systemic (Ismanto and Listyaningsih, 2019); and low levels of representation of their constituents (Amalia, 2011).

All of the above problems hypothetically lead to a process of political recruitment that does not prioritize meritocracy to produce members of the DPRD who are less able to carry out their duties and functions adequately as indicated above. However, meritocracy is necessary, especially by political parties that are essentially public bodies responsible for articulating and aggregating people's interests to be formulated into public policies that also favor the interests of the people, nation and state (article 1 paragraph 1 of Law Number 2 of 2011 ) through the legislators he recruits. Therefore the role and function of political parties is undoubtedly very big influence on the life of the nation and state (article 11 paragraph 1 of Law Number 2 of 2011), which demands the existence and management of modern and professional political parties, particularly in carrying out the functions of political 
recruitment.

However, political recruitment in Indonesia still faces complexity. The poor face of political recruitment is partly due to the lack of a formal, open, democratic and accountable political recruitment system among political parties in Indonesia. Some political parties even base their sources of political recruitment on the family environment and political relatives of the political elite itself, so that it tends to take place in a closed, exclusive and non-exotic manner. (KPK-LIPI, 2016). Sianturi (2014) concluded that the cause of the irrelevance of the Election System to the elected candidates was due to the non-functioning political recruitment function carried out by political parties. A similar study clearly concluded the magnitude of the influence of kinship factors in political recruitment in South Sulawesi (Purwaningsih and Subekti, 2017). While the Ismanto and Thaha (2016) found network and patronage factors in the nomination process in the 2014 elections in Banten Province.

Related to the background and previous studies above, this research was conducted to answer two key questions, namely: "how is the recruitment of candidates for legislative members in the Banten Province Golkar Party?" And "how much influence is the closeness and kinship and financial factors on the recruitment process? ". The two research questions will be explored based on the perspective of meritocracy theory whose operation is based on applicable legal norms, namely: Political Party Law, Election Law, Party Statutes / Statutes, and other implementing regulations. The limitation of the object of research in the Golkar Party was carried out because of two arguments. First, political parties are public bodies or organizations that operate in the public sphere, involve the public, and work in the public interest. Mukarom and Laksana (2015) identified public organizations as non-profit organizations, collectively owned by the public, ownership of resources not in the form of shares, and organizational decision making based on consensus. Meanwhile, according to Law Number 14 of 2008, public bodies can be in the form of executive, legislative, judicative bodies, and other bodies whose main functions and duties are related to the administration of the state, some or all of whose funds are sourced from the state budget and / or regional budget, or non-governmental organizations. as long as part or all of the funds come from the State Budget and/or Regional Budget, community contributions, and/or abroad. Meanwhile, the object of study is limited to the Golkar Party based on its existence as a large party with 
long experience, as well as its unwavering influence, although a number of cases have repeatedly shaken this party due to the involvement of its elite ruling in the vortex of corruption, both in the center and in the regions. .

\section{Methods}

This research was conducted qualitatively to describe the political recruitment in the Golongan Karya Party of Banten Province, by identifying the influence of kinship and financial capacity in the selection process of its legislative candidates in the 2019 general election. Interviews with several key informants were conducted, both party management, selection team, and some legislative candidates. Likewise, observation and documentation studies were carried out to explore research questions.

\section{Results and Discussion}

The Golkar Party has played an important role since the inception of Banten Province, through the active involvement of party figures several Banten Province formation organizations, both the Banten Province Establishment Committee (KPPB), and the Banten Province Formation Working Group (Pokja-PPB). The central role of these figures is even greater and influential after the merging of the two organizations in a new forum that coordinates the efforts to establish Banten Province, namely the Banten Province Formation Coordinating Board (Bakor-PPB) (Sutisna, 2001; Lubis, 2004; Ismanto, 2010; Nordholt and van Klinken, 2014). The great influence of these figures can be seen from the policies and dynamics of local politics, governance, and regional development that are colored by the thoughts, attitudes and actions of these figures. The success of the Golkar Party placed its cadres as the first Deputy Governor along with the United Development Party (PPP) cadres even though the Indonesian Democratic Party of Struggle (PDIP) was the absolute winner of the 1999 General Elections in Banten Province with 30\% of the DPRD seats, while the Golkar Party seats were only about half. Likewise, the success of the Golkar Party placed its cadres as governors from 2005 to 2013, the success of winning the chair of regents, mayors and deputy regents in six of the eight regencies / cities in Banten Province, as well as the success of winning the deputy governor's chair in the 2016 Governor Election. In the legislative 
realm, the Golkar Party won the 2004 General Election with $21.33 \%$ of seats in the DPRD, second in the 2009 Elections with 15.29\% seats amid the high determination of the rising Democratic Party with the acquisition of approximately $21.18 \%$; share the same number of seats with PDIP as the 2014 Election winners, namely 17.65\% of seats; and the success of maintaining $12.94 \%$ of DPRD seats in the 2019 elections amid the influence of PDIP as the ruling party with the acquisition of $15.29 \%$ of seats, and the determination of the Gerindra Party to win the election with the acquisition of $18.82 \%$ of DPRD seats.

All of the above facts are factual depictions of the influence of the Golkar Party in the local political constellation in Banten Province so that they can maintain their political position even with some cases that tarnished the party's face because of the involvement of several elites in criminal acts of corruption. Starting from the arrest of the Governor of Banten in a bribery case involving the Chair of the Constitutional Court in 2013, the arrest of party leaders who are also the husband of the Mayor of South Tangerang in 2013, the bribery scandal of the establishment of the Banten Bank in 2016 involving the Deputy Chairperson of the Banten Province DPRD, and operations arrest (OTT) Corruption Eradication Commission (KPK) against the Mayor of Cilegon in 2018. The cases above certainly do not include a number of corruption cases committed by the Golkar Party elite in Senayan, which not only tarnished the face of the party but also hypothetically had an impact on public trust in the Golkar Party.

The magnitude of the influence of the Golkar Party cannot be separated from the contribution of Haji Chasan Sochib as a central figure who played a very important role in the Golkar Party in the New Order era, during the process of forming the province, and after the formation of Banten Province until his death in 2011. Formally, he was Chair DPD I Advisory Board Banten Province Golkar Party until the end of his life. His actions as champions and businessmen effectively managed to consolidate the strength and influence of champions and businessmen to support the existence of the Golkar Party since the New Order era through a number of platforms that it formed, such as Persatuan Pendekar Persilatan dan Seni Budaya Banten Indonesia (PPPSBBI), Satuan Karya (Satkar Ulama), Chamber of Commerce and Industry (KADIN), Indonesian Businessmen Association (GAPENSI), Regional Daily Council of 1945 (DHD 45), and others. So it is not surprising that 
in a short period of time, he succeeded in establishing a strong political dynasty to date. The 2019 elections were another means of proving the still influence of this dynasty in the Golkar Party.

In Senayan, this dynasty succeeded in bringing three family members to Senayan, namely: the wife of the Deputy Governor of Banten (2017-2023) and previously served as the Deputy Chairperson of the Banten Province DPRD for the 2014-2019 Period; and the uncle of the Banten Deputy Governor who previously served as Mayor of Serang; and the younger brother of the Deputy Governor of Banten who managed to maintain his position as DPD member for the second period. At the local level, although in general the acquisition of Banten Province DPRD seats decreased from as many as 15 seats in the 2014 Election to 11 seats in the 2019 Elections, but still able to place most of the dynasty's cronies in the DPRD seats, six of which are old faces.

The Regional Management Council (DPD) I of the Banten Province Golkar Party (2015-2020) is led by the Deputy Governor of Banten who was the younger brother of the Banten Governor in the previous period (2005-2013) and also served as the Regent of Serang (2015-2020). In the previous period (2009-2015) the General Chairperson of the Golkar Party was led by the Governor's husband at that time (2005-2013), who was controversially elected because he defeated the previous General Chairperson (2004-2009) whose leadership was considered successful in bringing the Golkar Party through a difficult period of postreformation to win the 2004 and 2009 elections; and other senior figures of the Golkar party, which then had implications for the "exodus" of a number of senior party figures to other parties (Ismanto, 2017). Post-appointment in November 2013, the leadership of the Golkar Party was continued by the current General Chair who was previously elected to continue the party leadership in the 2009-2015 period through the Extraordinary Regional Conference in December 2013.

At the party management level, there are three close relatives of the General Chair who sit in the ranks of the deputy chairman, namely: Deputy Chairperson of the Human Resources Division who is held by the chairman's nephew who is now Deputy Regent of Pandelang (2015-2020), Deputy Chairperson of the Youth and Sports Division held by the chairperson of the general chairperson who is also the Deputy Governor of Banten, and the 
Deputy Chairperson of the Arts and Culture Division held by the wife of the Deputy Governor of Banten. Eleven other elements of the vice-chairman some still have kinship ties, and some others are categorized as business and political cronies who are considered to have high loyalty in this dynasty. Similar portraits are also found in the ranks of secretaries and deputy secretaries, treasurers and deputy treasurers, as well as the heads and members of the bureau.

In connection with the recruitment of prospective candidates for the Banten Provincial DPRD, the recruitment is carried out by a Provincial Level Selection Team of nine people, consisting of: Chairperson of the Provincial DPD, Daily Chairperson, Secretary, Treasurer, Deputy Chairperson of Organizational Affairs, Deputy Chairperson of the Cadre Affairs and Membership Division, Deputy Chairperson for Women's Empowerment, Deputy Chairperson for Youth and Sports, Deputy Chairperson for Legal Affairs, and Deputy Chairperson for Election Winning. With this composition, the selection team is practically very nuanced kinship and cronyism considering that 3 of them have family relations, 1 distant relative, and 5 others are dynastic loyalist cronies. The results can be confirmed by the correlation with the quality and recruitment results listed in the Banten Province DPRD Permanent Candidate List (DCT), which will be explained in the next section.

Quoting the opinion of Barbara Geddes (Labolo and Ilham, 2015) about the four models of political recruitment systems, one of which is meritocratic, namely political recruitment from highly competent circles such as technocrats, entrepreneurs, teachers, expert workers, and the like. This definition seems to refer to its grammatical meaning, namely: "a system in which the talented are chosen and moved ahead on the basis of their achievements" or "leadership selected on the basis of intellectual criteria" (merriamwebster.com). Whereas terminologically, the concept of meritocracy refers to the concept that was first coined by Michael Young (1961) in 1958 in a satirical essay about education and equality, that meritocracy is another form of oligarchy in the future. Meritocracy itself is conceptually formulated as (IQ + effort = Merit), which will be the basic value that sets the order of the ruling elite in the future (Celarent, 2009; Allen, 2011; Powell, 2016). Therefore contemporary definitions of meritocracy are generally formulated as "a social system in 
which rewards and positions are allocated justly on the basis of merit, rather than ascriptive factors such as genders, ethnic groups or wealth" (Lawson and Garrod, 2002), or " the principle by which resources, awards, pay, and positions are distributed along a system where performance is valued, regardless of other considerations such as equality, need, rights or seniority "(Heneman and Walker, 2005). Departing from this definition, meritocracy in this study was operationalized based on operational criteria used by the Golkar Party in carrying out its political recruitment, namely: achievement, dedication, discipline, loyalty, and impeccability (PDDLT), the process of which is regulated in the Golkar Party's Statutes / Articles of Association, as well as Party's Guidelines Number Juklak-11/ DPP/ Golkar/ V/2018.

There are some interesting findings occurred during the process of recruiting candidates for legislative members from the Golkar Party, namely the first mass resignation of 102 people from 171 prospective candidates determined by the Selection Team. The resignation of 102 candidates was largely motivated by financial reasons, namely his inability to provide a minimum fund of Rp.1.2 billion to finance his candidacy. On the other hand, it was found that the Selection Team was not optimal enough to select candidates because the 171 nominees had all been drawn from the list of functionaries or party members who had participated in the functionary orientation activities as required in the operational guidelines. While the fact is that participants in orientation activities are generally not party members who have been educated and selected in such a way as to be promoted as candidates but are delegates from the district/city level who are assigned without regard to qualifications or any factors other than their willingness to participate in these activities. This means that it can be concluded that political recruitment upstream is not proceeding as it should. On the other hand, the party's target to reach the minimum number of candidates as many as Banten Provincial DPRD seats failed to be realized.

Secondly, the opening of opportunities for the wider community to become a candidate for the Golkar Party legislative candidate has caused jealousy among party members considering that in practice there is privilege for them because they are not burdened with special conditions except for their popularity and ability to finance their nominations. The party even held a red carpet for external candidates with large financial 
capacities, rather than promoting party cadres who had "bled" to dedicate themselves to the party. Although not significant, the results were 9 external candidates out of a total of 69 candidates for the Banten Provincial DPRD from the Golkar Party. The nine candidates are mostly retired state civil servants (ASN), and some others are social organization activists and politicians who have moved parties. Unfortunately, all the external candidates failed to compete for seats in the DPRD.

Third, the Selection Team has no clear and measurable parameters for translating indicators of achievement, dedication, loyalty, and impeccability (PDDLT). As a result, the assessment of the eligibility of candidates tends to be subjective as can be seen from the renomination of DPRD members for the 2014-2019 period without going through an adequate evaluation of the PDDLT indicators. In fact, of the 10 incumbent candidates there was 1 candidate who was a former convict of corruption and was known as a business crony of the party ruling dynasty, and 1 other was an external candidate with the same status, who during ASN was known to be very loyal to the elite dynasty in this party. Nationally, the Golkar Party is even listed as the party that carries the most candidates who are ex-convicts of corruption, namely as many as 8 candidates (https://nasional.kompas.com). Besides, of the 10 incumbent candidates, 7 of them are also party administrators, and 3 of them are members of the Selection Team. And the result, 6 out of 10 candidates were successfully reelected as members of the Banten Province DPRD.

Fourth, although of the 69 names in the DCT there were no candidates with a very close kinship with the dynasty, most were confirmed as loyalist cronies with sufficient financial capacity. The results can be seen from 11 seats in the Banten Provincial DPRD, 6 of which were incumbent and administrators of the DPD I. Three members of the dynasty's core family in the 2019 elections were all projected and then succeeded in sitting in the DPR and DPD 2019-2024 period. And fifth, although AD / ART and Juklak Number 11 require senior high school as a minimum level of education to become candidates, in fact, there are approximately $30.43 \%$ of high school-educated candidates, which means they are not eligible according to the PDDLT parameters and applicable internal provisions.

The difficulty of the party to recruit a minimum number of targeted candidates with qualifications per the applicable terms and conditions is an indication of the party's failure 
to carry out political recruitment functions. Instead of producing candidates who are not only eligible but also qualified, the fact is that reaching the minimum amount cannot be achieved. The influence of the hegemonic dynasty, as well as the elitism that occurred among the party elites who were generally the business and political cronies of this dynasty, were the cause of the stagnation of party recruitment and regeneration. Moreover, coupled with the fact that being a party administrator and especially a candidate, is only possible by people with large financial capacities given the fact that political costs are very expensive. And this is the answer, why political party management and legislative candidates are generally crowded with business people at the local level, especially business people affiliated with party elites. Its capacity to finance its political activities, as well as great business opportunities to access government resources is an attraction that factually underpins the number of candidates with a business background to enter politics.

\section{Conclusion}

Although formally the Golkar Party adheres to meritocracy in its political recruitment, in reality, several adaptations have been made due to circumstances that are not possible. The demand to get as many seats as possible eventually becomes a pragmatic choice to determine the eligibility of candidates, namely electability that is proportional to their financial capacity. This condition causes the circulation of the elite to run slowly because incumbents have a much greater chance to be re-elected because of more ownership of the two variables in question. Meritocracy is not quite compatible with democracy, especially liberal democracy as practiced by Indonesia today. And ultimately meritocracy, as projected by Young (1958), is a utopia. Because what is now formed is an incompetent oligarchy, not a competent oligarchy popularly called the meritocracy.

\section{References}

Allen, Ansgar. (2011). Michael Young's The Rise of the Meritocracy: A Philosophical Critique. British Journal of Educational Studies, 59(4), 367-382. Retrieved from https://www.sheffield.ac.uk/polopoly_fs/1.155163!/file/philosophicalcritique.pdf Amalia, Luky Sandra. (2011). Kecenderungan Hubungan Anggota Legislatif dan Konstituen: 
Studi DPRD Provinsi Banten Hasil Pemilu 2009. Jurnal Penelitian Politik, 8(2), 287-297. doi: https://doi.org/10.14203/jpp.v8i2.467

Celarent, Barbara. (2009). The Rise of Meritocracy, 1870-2034 by Michale Young. American Journal of Sociology, 115(1), 322-326. 'Retrieved from http://www.jstor.org/stable/10.1086/605763

Haris, Syamsuddin et al. (2016). Panduan Rekrutmen \& Kaderisasi Partai Politik Ideal Di Indonesia. Jakarta: KPK - LIPI

Heneman, R.L. Walker, J.M. (2005). Merit pay: Linking pay to performance in a changing world, (2nd edition), Greenwich, CT: Information Age

Ismanto, Gandung. (2010, November-December). Ratu dan Raja Kecil di Tanah Para Jawara. Analisis Dokumentasi Hak Asasi Manusia (ASASI), pp. 11-14 retrieved from https://lama.elsam.or.id/downloads/1292825285_asasi_edisi_November-

Desember_2010.pdf

Ismanto, Gandung. Thaha, Idris. (2016). Banten: Islamic Parties, Networks and Patronage. In Edward Aspinall and Mada Sukmajati (Eds.), Electoral Dynamics in Indonesia: Money Politics, Patronage and Clientelism at the Grassroots (pp. 137-154). Singapore: NUS Press.

Ismanto. (2017). Tata Kelola Pemerintahan Provinsi Banten, Studi Tentang Aktor-aktor Kepemerintahan Daerah Tahun 2005-2013). Disertasi Program Doktor. Bandung: Universitas Padjadjaran

Ismanto. Listyaningsih. (2019). Pseudo Governance: A Lesson Learned From Banten. Working Paper presented in International Conference on Democratisation in Southeast Asia, 4th - 5th September 2019.

Labolo, Muhadam. Ilham, Teguh. (2015). Partai Politik dan Sistem Pemilihan Umum di Indonesia: Teori, Konsep dan Isu Strategis. Jakarta: PT RajaGrafindo Persada

Lawson, D. Garrod, J. (2002). The Complete A-Z Sociology Handbook, Boston: Penguin

Lubis, Nina. (2004). Banten Dalam Pergumulan Sejarah: Sultan, Ulama, Jawara. Jakarta: Pustaka LP3ES Indonesia

Nordholt, Henk Schulte. Gerry van Klinken. (2014). Politik Lokal di Indonesia. Jakarta: Yayasan Pustaka Obor Indonesia-KITLV-Jakarta. 
Powell, Stina. (2016). Gender Equality and Meritocracy: Contradictory discourses in the Academy. Doctoral Thesis. Uppsala: Swedish University of Agricultural Sciences Purwaningsih, Titin., Subekti, Valina Singka. (2017). Political Family and Intra-Party Democracy in Indonesia (A Study on the Political Recruitment of the Golkar Party during the Reform Era in South Sulawesi). Jornal of Government and Politics, 8(1), 141-165. doi: http://dx.doi.org/10.18196/jgp.8154

Sianturi, Kristina Agustiani (2015). Memperkuat Fungsi Rekrutmen Partai Politik. Jurnal Legislasi Indonesia, 12(1), ISSN 2579-5562. Retrieved from http://ejurnal.peraturan.go.id/index.php/jli/article/view/369

Sutisna, Agus. (2001). Banten Paska Provinsi: Mengawal Transisi, Membangun Demokrasi. Rangkasbitung: Lembaga Strategis Pembangunan Banten dan Partnership for Governance Reform in Indonesia.

Young, Michael. (1961). The Rise of The Meritocracy 1870-2033: An Essay on Education and Equality. Victoria: Penguin Books

Forum Masyarakat Pemantau Parlemen Indonesia. (2018). DPR 2014-2019 Dinilai Terburuk Sejak Era Reformasi. January 31, 2019, retrieved from https://www.cnnindonesia.com/nasional/20190131193542-32-365529/dpr-2014-2019dinilai-terburuk-sejak-era-reformasi

Indonesia Corruption Watch. (2019). ICW Bilang Kinerja DPR 2014-2019 Hanya Selesaikan 10\% dari Prolegnas. April 9, 2019, retrieved from https://nasional.okezone.com/read/2019/04/09/337/2041306/icw-bilang-kinerja-dpr2014-2019-hanya-selesaikan-10-dari-prolegnas

Indonesia Corruption Watch. (2019). Anggota DPR Kembali Ditangkap KPK, Kenapa Tak Pernah Jera?. August 9, 2019, retrieved from https://www.liputan6.com/news/read/4033224/headline-anggota-dpr-kembaliditangkap-kpk-kenapa-tak-pernah-jera https://wikidpr.org/news/kehadiran-anggota-dpr-pada-masa-sidang-ke-3-tahun-2017-2018 https://news.detik.com/berita/d-4690282/terobos-pelantikan-dprd-banten-mahasiswalempar-lempar-kertas https://www.bantennews.co.id/dinilai-tidak-patut-uang-perjalanan-dinas-dprd-banten-14- 
kali-lipat-dpr-ri/

https://www.beritasatu.com/nasional/350860/jaksa-40-anggota-dprd-banten-terima-suap https://nasional.tempo.co/read/753889/skandal-bank-banten-pimpinan-dprd-mengakuterima-suap

http://www.rmolbanten.com/read/2019/08/22/10876/Kumala-Tak-Puas-Kinerja-DPRDBanten-

https://www.merdeka.com/peristiwa/dari-84-anggota-dprd-banten-hanya-1-anggota-yanglaporkan-lhkpn.html

https://www.merriam-webster.com/dictionary/meritocracy\#h1

https://nasional.kompas.com/read/2019/01/31/11240081/golkar-usung-8-caleg-eks-koruptorini-daftarnya?page=all. 